\title{
M. C. Sloss and the California Supreme Court
}

Frank H. Sloss*

Early in the year 1906, Governor George C. Pardee offered Marcus C. Sloss the post on the California Supreme Court vacated by the death the preceding Christmas Day of Associate Justice Walter Van Dyke. Max Sloss, as he was commonly known, was a young San Franciscan who had just completed five years of a six-year term as Superior Judge to which he had been elected in 1900. The appointment was more than unsolicited; it was so unexpected that when Judge Sloss received the telephone call from the Governor, he half-suspected a bit of playful banter on the part of a relative addicted to such pranks, and was saved only by a combination of innate caution and good luck from responding in that vein.

When Justice Sloss took his seat on the supreme court on February 1, 1906, he was not yet 37 years old. In November, 1906, he was elected for the unexpired balance of Van Dyke's term, and in November, 1910, he was re-elected for the ensuing full twelve-year term. On February 28, 1919, his fiftieth birthday, he resigned to resume the practice of law. His period of service was just over thirteen years-from shortly before the San Francisco earthquake and fire to shortly after the end of World War I. For lawyers accustomed to browsing in the California Reports, the period can be identified as runming from Volume 148 to Volume 180.

This paper, written only a few months after Judge Sloss's death, was prepared im response to a request for information on his contributions to the development of California law while on the bench. It is therefore inevitably an exercise in legal history. To be appreciated, the matters to be discussed must be seen in that perspective. The activities of the California Supreme Court, moreover, are inevitably a part of the history of California as a whole, no inatter how much judicial detachment the justices may pursue or achieve. And California's history from 1906 to 1919 was turbulent and colorful. In the earlier volumes, we are repeatedly made aware of how profoundly San Francisco, then the unchallenged metropolis of the state, had been shaken, both physically by the catastrophe of 1906 and spiritually by the graft scandals culminating in the removal of Mayor Schmitz on his conviction for extortion and the imprisonment of the political boss, Abe Ruef. ${ }^{1}$ We sense, too, the beginnings of the explosive growth of Los

* Member, San Francisco Bar. .

1 See, for example, McKannay v. Horton, 151 Cal. 711, 91 Pac. 598 (1907). Mayor Schmitz, although convicted, had appealed, and continued to issue orders from the jail as mayor, while his secretary retained possession of the temporary mayor's office set up after the fire. Meanwhile a new mayor, with his secretary, operated in the new City Flall. The court had to decide which secretary was entitled to the salary. The unanimous decision went against Schmitz. 
Angeles. ${ }^{2}$ A little later come the political and legislative upheavals associated with Governor Hiram Johnson and the Progressive movement, which confronted the California courts with a series of constitutional challenges not unlike those that later plagued the United States Supreme Court in the New Deal era. As our period ends, there are the repercussions of war, and the first skirmishes in the bitter controversy over Tom Mooney's conviction for the Preparedness Day bombing. ${ }^{3}$ Rural California, too, is in rapid transition, and the reader of these reports can never forget for long the mighty irrigation developments that bred endless litigation and the creation of much new law in the field of water-rights. The infant oil industry is reflected here, as is the emergence of the power of organized labor. So, too, is the beginning of twentieth-century social welfare legislation.

There is much that is quaintly archaic. Horses amble through these pages; they draw their wagons, and return to their stables, where they are tended by members of a stablemen's union; for the first few years the word "automobile" does not appear in any supreme court decision. There are street-cars, but no buses; trains, but no planes; telephones, but no radios; and not a hint of the motion picture industry.

But enough about the times; we must move on to the characteristics of the court itself, for it too was very different in those days.

Today, in the vast majority of cases, appellate review begins and ends in the intermediate appellate courts. The Supreme Court of California, like the Supreme Court of the United States, hears initially only cases of a few exceptional kinds, and grants ultimate review of other appeals only when warranted by the importance of the questions presented or the need to secure uniformity or to correct manifest error. But in the period we are considering, this conception of restricted review had not yet taken shape. True, the district courts of appeal had just been created; but their jurisdiction was much more limited than now, and they were viewed primarily as a device for assisting the supreme court by relieving it of very petty cases and giving preliminary screening to some others. The supreme court continued to handle the major appellate load. This reflected itself in many ways. The sheer number of decisions ground out by the court in a single year is enormous by present standards, and a great many of them would now be considered far too trivial to warrant attention by the court of last resort. This condition put a premium on brevity and conciseness of statement in the opinions.

To keep up its output, the court did much of its work in department.

2 See People v. City of Los Angeles, 154 Cal. 220, 97 Pac. 311 (1908), which sustained the validity of the annexation of the long, narrow strip that first gave Los Angeles its access to the sea.

3 People v. Mooney, 177 Cal. 642, 171 Pac. 690 (1918). 
The department system has long since lapsed into disuse, no doubt for the reason already suggested. Nowadays, the usual supreme court case has already been heard and decided by a three-judge court of appeal, and then considered on petition for hearing. At that stage, to assign it to still another panel of three judges sitting as a department of the supreme court, and then to entertain still another petition for hearing in bank, would add one layer too many to the appellate cake. But during the years we speak of, the department system was in full flower, a fact that can never be forgotten in appraising the work of a particular justice. Each department, so far as its own work went, had a good deal of independence; it could adopt its own methods of assigning cases and announcing decisions. Each associate justice was for practical purposes a member of two separate, though interlocking, courts-his own department and the full bench. His most intimate association was with his departmental colleagues; and when, as in the period we are discussing, each department was operating harmoniously, its members influenced each other and a departmental view of legal issues was likely to emerge. We find that in the relatively few but exceptionally difficult or important cases in which the court disagreed, the division was more bikely than not to coincide with the departmental lines.

This brings us to the personnel of the court, which cannot be overlooked, for an appellate judge is not a solo performer, and the appreciative listener must be aware of every voice in the orchestra. Many of these voices are well worth hearing, for this was a strong court.

In 1906, when Justice Sloss came to the court, the Chief Justice was the venerable and distinguished W. $H$. Beatty. As Chief Justice, he did not ordinarily sit in either department, and he wrote less than the usual number of opinions in bank, for he devoted much of his time to a painstaking study of the numerous applications for writs and petitions for rehearing or for hearing after decision in department or in one of the district courts of appeal. His keen, thorough mind is best seen through those petitions, for he was constantly dissenting from orders denying hearings, often with an opinion explaiming why he considered some fine point worthy of more careful examination.

Justice Sloss was assigned to Department One, where he had the lasting good fortune to be associated with two men for whom he rapidly developed the utmost liking and admiration-Justices Lucien Shaw and Frank M. Angellotti. For years to come, Department One was to operate like a well lubricated mechanism of great efficiency and high power. The opinions poured out with sureness of touch, clarity of expression, and skill in legal reasoning rarely surpassed by any triumvirate of judges. ${ }^{4}$

4 Although cases were normally assigned in rotation, it becomes evident from the reports that the Department One justices must have traded frequently annong themselves in the writing both of department decisions and of those opinions in bank that had fallen to any one of them. 
Department Two at the outset consisted of Justices T. B. McFarland, F. W. Henshaw, and W. G. Lorigan. Before the end of 1908, Justice McFarland died and was succeeded by Henry A. Melvin. Department Two was also a harmonious unit, but its members, though all able judges, do not emerge in the books as a partnership comparable to that of Department One. The reader is constantly aware of the towering personality of Justice Henshaw, whose magnificent intellectual and literary efforts tend to overshadow those of his associates.

The next change did not occur until 1914. In August of that year, the old Chief Justice died. He had not intended to serve beyond the term that was about to expire, and the candidates to succeed him had already been nominated. To fill the interim of a few months, Governor Johnson tendered a complimentary appointment to Matt I. Sullivan. In November, Justice Angellotti was elected Chief Justice, and William P. Lawlor was elected to the place he vacated as an associate justice. This alteration in Department One personnel made less change than might have been expected. Partly, perhaps, through deficiencies in his training and experience, partly through indolence, and partly because of a prolonged illness, Justice Lawlor made small impact on either the court or the department, whether in terms of number or quality of decisions. Justices Shaw and Sloss, with the aid of judges sitting pro tem., continued to carry the load, and Chief Justice Angellotti remained at least in philosophy a member of the old Department One team..$^{5}$

Thus, Shaw was apparently the specialist on water law; an Angellotti or Sloss water opinion is a rarity, unless Shaw was absent or disqualified. Angellotti has a similar near-monopoly (within the Department One group) of the criminal cases. In exchange, Sloss seems to have taken over most of the cases involving intricate corporate and financial problems. No such pattern is seen among the Department Two justices; they apparently took the cases as they came. Another Department One innovation, inspired by the custom of the English courts, was the practice of conferring on cases before they were heard, agreeing on a tentative decision, and, if nothing was said in the oral argument to change or shake their views, announcing the opinion orally froin the bench then and there. Nineteen cases were so treated in 1915, but only one in 1916, and none thereafter. The experiment was abandoned because of criticisms from the Bar; lawyers complained that an immediate decision gave thein the feeling that the court had not adequately considered the oral argument.

5 When indulging in reminiscence, Judge Sloss used to recall with amusement the time when he and Shaw, weary of repeatedly picking up Lawlor's unfinished cases for him, resolved to do so no more. The result was that the Department One justices soon became unable to make the monthly constitutional (Art. VI, Sec. 24) affidavit that no cases submitted longer than 90 days remained undecided, without which they could not draw their pay. This went on until all three were eleven months bchind in their salaries. It was Shaw and Sloss who weakened first; once again they divided the accumulation between themselves and cleaned it up. Meanwhile, when Lawlor did produce an opinion, he was likely to turn the simplest case into an ostentatious display of apparent learning and industry. The degree of irritation whicb this aroused even in the notably courteous Shaw can be sensed from In re Gilstrap, 171 Cal. 108, 152 Pac. 42 (1915), in which, after a twelve-page Lawlor opinion, Shaw's brief concurring opinion opens: "I see nothing in this case requiring claborate statement, prolonged discussion, or the citation of many authorities." Sloss concurred in both opinions, thus saying, in effect, that he agreed with what Lawlor said, but also agreed that most of it need not have been said. 
The only additional changes occurred too late in the period of Justice Sloss's service to have much influence on his judicial career. At the beginning of 1918, Curtis D. Wilbur replaced Justice Henshaw, who had resigned, and at the start of 1919, Thomas J. Lennon succeeded Justice Lorigan, who had not sought re-election.

In summary, then, the memorable personahities among Justice Sloss's associates are Chief Justice Beatty, the capable and congenial Department One colleagues, Justices Angellotti and Shaw, and the compelling, enigmatic and tragic fignre of Justice Henshaw. Those are the ones of whom he spoke most often in later years. ${ }^{8}$

\section{QUANTITY aND QUALITY}

The Reports contain no fewer than 583 opinions by Justice Sloss. Of these, 323 were prevailing opinions for Department One, 236 were prevailing opinions for the court in bank, 17 were concurring opinions, and 7 were dissenting opinions. The cases written by other justices in which his participation is noted reach the total of 1801 . In 641 of these he joined in a department decision; in 1110 he subscribed to the prevailing opinion in bank; in 30 he recorded a concurrence in the judgment but not in the mam opinion; and in 20 he cast a dissenting vote. This was a hard-working court, and he carried his full share of the load. As the figures show, he wrote more than his one-third of the department cases, and far more than his one-seventh of the bank cases.

Even these impressive totals do not measure the entire volume of judicial work performed; two additional classes of matters cannot be tabulated. In cases decided in department in whicl a hearing in bank was granted afterwards, the original departnent decision was vacated and dropped from sight unless the author of the final opinion in bank chose to adopt, quote or mention it. Also, participation in the denial of petitions for hearing or for rehearing and in the relatively few full opinions rendered per curiam cannot be tallied for it was not usually the practice to publish the votes of individual justices.

Sheer bulk, however, is not the chief measure of a judge's accomplish-

6 There is, however, one McFarland anecdote worth recording. Justice McFarland was a sturdy, bearded relic of the pioneer era, vigorous and independent in thought and action; in conference, when some of his colleagues favored granting a hearing after decision in the court of appeal, he liked to say: "Let it alone; those fellows have decided it and they're just as likely to be right as you are." The anecdote concerns his pleasant custom of pausing daily at his favorite bar on the way home. Once a newspaper gossip columnist commented that it was not an edifying spectacle to see Justice McFarland of the supreme court drinking cocktails day after day in such-and-such a saloon. McFarland was indignant, and told his associates he proposed to bring action for libel. One of them ventured to ask him in what respect the item was false. "Cocktails!" the old justice snorted, "He said 'cocktails'. Why, I haven't had a mixed drink in thirty years." 
ment. What of the content of these decisions? The significance of some of them in the development of California law will be discussed later. We may, however, pause at this point for a few comments on their style. The reader who is looking in these volumes for shafts of sardonic wit, for striking flourishes of rhetoric, for words and phrases that catch the imagination by their novelty, for ornamental quotations from Latin or English poetry, should not search in Justice Sloss's opinions; it is Justice Henshaw's that he will happily linger over. Yet Justice Sloss was also a beneficiary of the sound classical education of his day and went through life in full command of a wide vocabulary and a sensitive, even fastidious, taste in the selection and use of words. In his opinions, too, there was mastery of language, but its presence is so unostentatious that it can easily go unnoticed. He searched first for the word that would convey the desired meaning as precisely as possible, but as between two words that would serve equally well he preferred the simpler, shorter, or more familiar. His construction of sentences followed the same principle. Clarity came first, for his prime objective was to express thought with the utmost exactness attainable; he did not wish to distract the reader from the matter to the manner. The desired lucidity was almost invariably achieved; brevity and forecefulness came as byproducts. There is beauty in this style, but it is not the beauty of a consciously created work of art. It is rather the beauty of a work of enginering - a dam or bridge that pleases the senses simply because its design is exactly right for the purpose it is to serve.

Judge Sloss had, however, no lack of appreciation for the more ornate or artificial style, when it was skillfully employed by others. On the contrary, he relished and admired the epigrams of Holmes, the literary elegance of Cardozo, the brilliant verbal pyrotechnics of his colleague Henshaw. Even in later years, when the old respect for Henshaw as a man had inevitably been shattered by the disclosures revealing Henshaw's apparent corruption in office, appreciation of his talents remained. Judge Sloss never ceased to savor and frequently to quote Henshaw's extraordinary sentence in the Lucky Baldwin case: "To declare that the holy state of matrimony is shown by this low, lecherous liaison, this clandestine commerce, compounded of concupiscence and cupidity, would be to the mind of woman as abhorrent as to the mind of man it is preposterous ... ."7 The Henshaw phrase "benıusing euphemisnı" gave him lasting pleasure although it occurs in a powerful dissent aimed at one of his own leading opinions. ${ }^{8}$ Another of his favorite passages was Henshaw's reply to the contention that a corporation should not be heard to complain of an unconstitutionally levied tax when admittedly the amount of the tax was no more than could prop-

7 Estate of Baldwin, 162 Cal. 471, 491, 123 Pac. 267, 276 (1912).

8 Western Indemnity Co. v. Pillsbury, 170 Cal. 686, 720, 151 Pac. 389, 412 (1915). 
erly have been imposed: "Thus, if a man who is on his way to church to give a hundred dollars to charity is robbed of that hundred dollars by a highwayman, his financial condition is exactly the same as it would have been had he carried out his purpose. Yet it will not be said that this fact leaves him uninjured and without grievance." ${ }^{9} \mathrm{He}$ was fond, too, of recalling the cas $\mathrm{e}^{10}$ in which the City of Los Angeles, prevented by the state constitution from taxing insurance companies, sought to impose license fees on insurance agents, and Henshaw, pointing out that the companies could not hive without agents, added that they "may well be heard to voice Shylock's expostulation:

You take my house when you do take the prop

That doth sustain my house; you take my life

When you do take the means whereby I live.

But in exposition of the fact that this principle does not rest upon the authority of Shakespeare alone a reference may be made to" eight cases. There are many other fine examples. ${ }^{11}$

Admiration, however, did not mean emulation. Those acquainted with Judge Sloss's private correspondence and conversation know that the ironic

${ }^{0}$ Albert Pick \& Co. v. Jordan, 169 Cal. 1, 16 (1914). Inexplicably, the Pacific Reporter's version of the opinion (145 Pac. 506) omits these two sentences.

10 Hugles v. City of Los Angeles, 168 Cal. 764, 145 Pac. 94 (1914).

11 The discriminating collector of Henslaw items will observe the astonishing vocabulary. Surely few other judges but Mr. Justice Frankfurter, and few other lawyers but the fictional characters of $B y$ Love Possessed, would casually scatter through their prose such words as "attingent" (in the flowing phrase "cognate, attingent and germane," describing the relationship that is required to exist between the title and the subject of a legislative act-Ex parte Hallawell, 155 Cal. 112, 114, 99 Pac. 490, 492 (1909)) ; "apodictic" (Albert Pick \& Co. v. Jordan, 169 Cal. 1, 17, 145 Pac. 506, 512 (1914)); and "lermeneutics" (Western Metal Supply Co. v. Pillsbury, 172 Cal. 407, 429, 156 Pac. 491, 500 (1916)). The Pick case, already cited twice, is superb throughout, especially the peroration, in which Henshaw, having with devastating logic exposed the inconsistency anong the United States Supreme Court decisions about taxes on, or measured by, the capital stock of a foreign corporation, proceeds, with exquisite effrontery, to say: "We are constrained to admit our inability to harmonize this language and these decisions, though we make liaste to add that undoubtedly the failure must come from our own deficient powers of perception and ratiociation, and for this deflciency it is no consolation to us to note that our brethren of the supreme court of Montana are similarly afflicted ...." (169 Cal. at 24, $145 \mathrm{Pac}$. at 515.) It is perhaps not astonisling that the United States Supreme Court took no notice of this opinion; it merely affirmed per curiam (244 U.S. 647 (1917)). Equally striking and delightful is Matter of Dart, 172 Cal. 47, 155 Pac. 63 (1916), in which Henshaw castigates a Los Angeles attempt to prolibit solicitation for charity without a permit to be granted (or withleld) in the absolute discretion of a city commission. Once again, Henshaw draws on "The Mercliant of Venice," this time to affirm that the quality of mercy is not strained; it droppeth as the gentle rain from Heaven. "But in Los Angeles," he proceeds, "it is to be strained, and drop as froun a sprinkling-pot in the guiding hand of the Charities Commission." Another poetic excerpt follows, this one from Joln Boyle O'Reilly, concerning

The organized charity, scrimped and iced

In the name of a cautious, statistical Christ. 
twist, the trenchant thrust, the apt allusion came naturally to him; but they were rigorously excluded from his judicial writing. ${ }^{2}$

\section{Six Notable Decisions}

We have already noted that a large proportion of the cases reported in the period under review appear trivial by present supreme court standards. Other decisions, although important at the time, have become obsolete through subsequent statutory changes. Barely one-tenth of the opinionssay 60 out of Justice Sloss's 583-have lasting legal or historical interest. Of these, a half-dozen stand out as major accomplishments.

1. Constitutionality of the McEnerney Act-Title and Document Restoration Co. v. Kerrigan ${ }^{13}$

One of the many disastrous consequences of the San Francisco earthquake and fire was the destruction of the contents of the office of the Recorder, leaving no record title to any real property in the City and County. The Legislature, in extraordinary session, authorized a new court proceeding to establish title to real property in case of destruction of the public records. The possessor of land could prove ownership, by oral testimony if necessary, and procure an adjudication good against the world. The plan was named after its principal designer, the gifted Garret W. McEnerney, and to this day every San Francisco real estate title originates in what is still called a McEnerney decree; but when it was new the act shocked many of the legal minds of the day. When first presented with an order under the act, one of the San Francisco Superior Judges declined to sign it, believing the act unconstitutional. An application for writ of mandate brought the question to the supreme court.

The most formidable objection to the act was the fact that persons who might be the true owners of interests in San Francisco property, but whose identity or whereabouts were unknown, could forever lose their rights by a proceeding against "all persons" of which they were given no notice beyoud publication and posting. This was claimed to deprive them of property without due process of law.

The unanimous opinion by Justice Sloss, after summarizing the statute,

12 Part of his code of judicial good manners was that a judge may vigorously attack a view, but should not abuse or deride the man who holds it. Still, with all his restraint in the face of arguments he might consider erroneous or unsound, his patience sometimes wore thin when confronted with sheer imcompetence. In one such situation, Justice Sloss wrote: "The complaint contains a mass of averments having no substantial relation to any cause of action that appears. Indeed, it is difficult to extract from the extended narration of the pleading a definite idea of the cause of action which plaintiff intended to set up. The consideration of the various points may be clarified if, adopting the suggestion of one of the respondents, we first undertake to ascertain what causes of action are not stated." (Kinley v. Thelen, 158 Cal. 175, 182, 110 Pac. 513, 516 (1910)).

13150 Cal. 289, 88 Pac. 356 (1906). 
strikes the keynote by dwelling on the importance of its object. While recording is not inherently necessary for the establishment of the ownership of property, in practice a title that cannot be substantiated in the public records is unmerchantable. The new method of restoring title, though described in the statute as a proceeding in rem, did not quite fit the recognized forms in that category, but there were analogies with proceedings quasi in rem, and with the ancient equitable suit to quiet title and its code equivalent. Further support was found in decisions in some states upholding the Torrens system of land registration, though other courts had held otherwise. This led to the carefully reasoned conclusion that the act should be upheld. ${ }^{14}$

The decision reveals much of Justice Sloss's fundamental attitude toward constitutional considerations. There is the practical approach, with stress on what the Legislature had tried to do and what good reasons might be found for the attempt. The presumption of constitutionality becomes a living reality, not merely a conventional form of words. There is, too, the conviction that traditional legal conceptions and forms should be subject to molding by the Legislature to meet new conditions. Legal learning is used as a guide, not a strait-jacket. Between conflicting lines of authority, the one which gives freer scope to legislative action is preferred.

\section{How far can labor unions go? Parkinson Co. v. Building Trades Council ${ }^{15}$}

This decision is a leading case by any definition. It pointed the course by which California labor law was to advance, and has found its way into principal case-books on torts as well.

The plaintiff, a seller of lumber and building materials, had kept in its employ a man who refused to join the union. The union called a strike and in addition notified the plaintiff's customers that union members would not work for them so long as they continued to do business with the plaintiff. There was no picketing and no substantial claim of threats of violence. The trial court granted an injunction against the "secondary boycott"that is, the effort to bring pressure on the plaintiff by striking his customers.

Six of the supreme court justices concurred in reversing the injunction, but not on the same grounds. Of the three opmions in favor of reversal, Justice Sloss's alone comes to grips with the basic question: is the secondary boycott - the refusal to deal with those who deal with the original party to the dispute - a legitimate weapon in a labor controversy? The

14 This case was not taken to the Supreme Court of the United States; but another case involving the McEnerney Act arose in the federal courts, and the circuit court of appeals certified the question of the validity of the Act to the Supreme Court. The Supreme Court, in a unanimous decision by Chief Justice White, upheld the statute, drawing heavily on the language and the reasoning of the Kerrigan case. American Land Co. v. Zeiss, 219 U.S. 47 (1911).

15 154 Cal. 581, 605, 98 Pac. 1027, 1037 (1908). 
opinion cites authorities both ways, and deliberately selects the view favorable to the rights of the labor organization. Considerable reliance is placed on the celebrated Massachusetts dissenting opinion of Justice Holmes in Vegelahn v. Guntner, ${ }^{16}$ and while Justice Sloss does not repeat the broad philosophical reflections of that opinion, he quotes with approval the passage stating that labor ought in fairness to have the same freedom as capital to gain greater strength by acting in combination.

Neither of the other opinions meets this issue head on. Chief Justice Beatty took the view that, since union regulations made the secondary boycott inevitable, the warning to the plaintiff of what would happen was harmless or even laudable, and did not constitute a threat warranting an injunction. This will not bear analysis; it is the boycott, and not the threat or warning of it, that hurt the plaintiff. Justice Angellotti believed that a boycott did not under any circumstances constitute a legal injury, and that the question of motive was immaterial. That view has not stood the test of time; in the light of the subsequent development of the law on interference with business relations, it is clear now that there is no absolute legal right to institute a boycott regardless of purpose. Thus, the Sloss opinion, although it bears his signature alone, is the one that announces the rule for which the case has come to stand-that the secondary boycott is a legitimate weapon in a labor dispute. ${ }^{17}$

It is to this opinion, more than any other, that California law owes its growth in a direction generally favorable to the rights of labor. Whether this development has been for good or ill, the importance and influence of the opinion are beyond question. ${ }^{18}$

3. Getting the law of trusts back on the track-Estate of Spreckels ${ }^{10}$

A lawyer reading the will of Claus Spreckels today would find nothing startling in it. He would hardly suspect that it was carried into effect only through a striking piece of judicial statesmanship in the highest court of the state.

For a will disposing of more than ten million dollars of property, it is unusually short and simple. It leaves the entire estate to trustees, who are directed to pay the income to the widow for life and then to divide the

16167 Mass. 92, 44 N.E. 1077 (1896).

17 The case was cited for that proposition a year later in Pierce v. Stablemen's Union, $156 \mathrm{Cal} .70,103 \mathrm{Pac} .324$ (1909); its doctrine is there called the "truer and more advanced," despite its disagreement with decisions of the English courts, the federal courts, and many state courts.

18 The Parkinson case may have been the origin of Judge Sloss's lifelong interest in labor matters, and of his reputation for impartiality in such controversies, which led to his selection as a member of the arbitration board in the San Francisco building trades dispute of the 1920's, as arbitrator for the Port of San Francisco and for the Pacific Coast following the bitter waterfront strike of 1934, and as a public member of the Regional War Labor Board in World War II.

10162 Cal. 559, 123 Pac. 371 (1912). 
estate into three equal parts, two of which are to be delivered to two of the testator's sons and the third to be held in trust for his daughter for life and then to go to her children.

Lurking in the background, however, ready to pounce on this will and destroy it, was the anomalous rule laid down in Estate of Fair. ${ }^{20}$ The will of Senator Fair, like that of Mr. Spreckels, attempted to dispose of an estate of many millions according to an entirely natural scheme. The estate was to go in trust for the benefit of the testator's three children during their lives. After the death of all of them, the trustees were to convey one-half of the estate to the children of the testator's daughters and the other half to his nephews and nieces. The validity of the will was attacked under the peculiar code provisions then in force in California himiting the purposes for which a trust of real property could be created. First the Califorma Supreme Court upheld the will by a vote of four to three; on rehearing, one justice switched his vote, and the final decision denied effect to the will and awarded the estate outright to the three children. The ground was that the ultimate beneficiaries received no estate in the property, but only a personal right to enforce the trust. The remainder interests, therefore, were vested solely in the trustees and they would ultimately hold title only for the purpose of making conveyance. The trust accordingly existed for the purpose of conveying the property, which was not one of the trust purposes permitted by the code. Hence the entire trust plan failed. Thus was established the rule that in California a trust to convey was invalid.

By the time the Spreckels case reached the Supreme Court, only two of the justices who took part in the Fair case remained. The newer justices must have been heartily tired of the Fair rule, which required them repeatedly to strike down testamentary plans of the most innocent kind. Still, they were conscientious judges of an era in which adherence to precedent, especially in matters affecting rules of property, was a duty more binding than it is now considered to be. This presented them with a dilemma that they turned into an opportunity.

Fortunately, the language of the two wills was not identical. If the Spreckels will could be interpreted as devising a direct property interest to the remaindermen, so that the direction to convey became a means to an end rather than the purpose of the trust, a different conclusion could be reached. The elaborate opinion rendered by Justice Sloss takes that approach. Enough authority is marshalled to justify the outcome, but there is a candid admission that in cases like this "the court has been keen to search for words which might save the testamentary attempt from failure."21

By seizing on a few extra words in the Spreckels will, perhaps not

20132 Cal. 523, 60 Pac. 442, 64 Pac. 1000 (1901).

21162 Cal. at 569, 123 Pac. at 375. 
enough to create any substantial difference but sufficient to satisfy the court's conscience, it became possible to distinguish the Fair case and, in effect, to end the baleful influence of its rule long before the Legislature got around to repeahing the troublesome code section. From the time of the Spreckels decision, any lawyer who wanted to circumvent the Fair case could find out how to do it. ${ }^{22}$

\section{What is a miscarriage of justice? People v. O'Bryan ${ }^{23}$}

Criminals, everyone would agree, should be brought to justice, but only by fair and proper legal procedure. According to traditional doctrine, if an appellate court found error in the record of the trial, it was to be presumed that the defendant had been prejudiced. Reversal of the conviction followed. It came to be widely felt that there were too many reversals based only on "technicalities." 24 In 1911 a new provision, section 41/2, was added to Article VI of the state constitution, providing that a judgment in a criminal case should not be reversed "unless after an examination of the entire cause including the evidence, the court shall be of the opinion that the error complained of has resulted in a miscarriage of justice." This section first came before the supreme court in the O'Bryan case.

22 Hidden under the controversies over the demerits of the Fair rule, and unknown even to the participants in the Spreckels case, was an added element of drama. It was the Fair case that ultimately brought about the downfall of Justice Henshaw. He was the judge who had switched his vote to create the majority that destroyed the Fair trust. In 1918 it was revealed, with the support of apparently unimpeachable documentary proof, that he had received a bribe of $\$ 400,000$ from the Fair heirs. The man who gained possession of the facts, and subsequently published them, was Fremont Older, the militant, crusading editor of the San Francisco Bulletin and later of the San Francisco Call. His account of the astonishing chain of circumstances by which the evidence survived the great fire and years later came to his knowledge can be found in his autobiography, My Own Story (Macmillan, 1926). Older also tells how, having learned the story late in 1917, he confronted Justice Henshaw, and agreed to keep silent if Henshaw would resign and comply with certain other conditions. Henshaw did indeed resign. The other conditions, according to Older's account, concerned the Mooney case (note 3 supra), then a subject of the most violent controversy. Henshaw, says Older, agreed to switch sides; he was to break off his personal and pohtical connections with the District Attorney in charge of the Mooney prosecution, and to add his voice to the pleas being made by Older and others on Mooney's behalf. A year later, asserting that Henshaw had violated the terms by remaining in contact with the District Attorney, Older felt himself justified in publishing the sensational tale of the bribery, and did so (San Francisco Call, November 22, 1918). Henshaw never admitted the truth of the charge, but his denials, unhappily for those who admired him, were not convincing (San Francisco Chronicle, Novenber 23 and 24, 1918, and June 3 and 6, 1919); and he never sought judicial vindication through a libel suit. The rather pitiful last years that closed a once brilliant career can be sensed from the tone of his obituaries (San Francisco Chronicle and San Francisco Examiner, June 9, 1929). To his colleagues, Henshaw's unexplained resignation came as a surprise, and the subsequent revelations as a painful shock. Judge Sloss often spoke of him afterwards, always sadly; sonietimes with a philosophical comnent about the futility of bcing endowed with all other gifts if character is lacking, and invariably with lurking resentment of Older's sorry role in the catastrophe.

23165 Cal. 55, 130 Pac. 1042 (1913).

24 Judge Sloss liked to recall that soneone had defined a technicality as "any unanswerable point raised by the other side." 
As Justice Sloss saw the case, there had been one substantial error; statements made by the defendant had been received in evidence under circumstances amounting to an invasion of his constitutional right not to be compelled to be a witness against himself. Under the new provision, it became incumbent on the court to examine the entire case "including the evidence," and to form an opinion as to the existence of a "miscarriage of justice." What in the world did that mean?

The opinion explores this novel problem, on which no precedent existed, most thoughtfully. It is recognized at the outset that the phrase "miscarriage of justice" is as vague and as incapable of precise definition as "due process of law." Does the amendment mean that the appellate court must put itself in the place of the jury and if it believes the defendant guilty disregard the means by which the conviction was obtained? Clearly not, for by "justice" in Anglo-American criminal law "we mean something more than merely ascertaining whether an accused is or is not guilty. It is an essential part of justice that the question of guilt or innocence shall be determined by an orderly legal procedure, in which the substantial rights belonging to defendants shall be respected." 25 If, then, the defendant's rights, especially constitutional rights, have to some degree been invaded, does it follow that the judgment must be reversed? Again not, for then the amendment would have changed nothing. The answer stated in the opinion lies between these extremes. The amendment has at the very least reversed the old presumption that error was prejudicial. If the appellate court believes that the error, although substantial, did not affect the result, and that the result was just, the judgnient should be affirmed.

Further than that the court could hardly be expected to go in its first case. ${ }^{26}$ It is, however, the basic analysis first made by Justice Sloss that blazed the trail the California courts have subsequently traveled.

25165 Cal. at 65, 130 Pac. at 1046.

26 Even that much of an attempt to formulate the operation of section $4 \mathrm{~T} / 2 \mathrm{did}$ not meet with the whole court's approval. Angellotti and Shaw-the Department One colleagues-joined in the Sloss opinion. The court's other wing differed. Lorigan, with the agreement of Henshaw and Melvin, was not prepared to discuss the effect of section $4 \frac{1}{2}$, and was able to postpone the necessity of doing so by concluding, in a concurring opinion, that the error had been cured without resort to the new amendment. In People v. Griesheimer, $176 \mathrm{Cal} .44,167 \mathrm{Pac} .521$ (1917), this difference of approach widened into a sharp cleavage. Chief Justice Angellotti wrote an opinion disposing in the usual way of claims of error in the information, the instructions, and the admission of evidence, concluding with the observation that the case falls clearly within section $4 \mathrm{I} / 2$; Shaw, Sloss and Lawlor concurred. Curiously, Henshaw, with the agreement of Lorigan and Melvin, was provoked into an extraordinarily long and exceptionally bitter dissent. He even hurls a direct challenge into the Chief Justice's teeth by quoting a series of questions -like an examination-addressed by him to the Chief Justice concerning his views on section $4 \mathrm{~T} / 2$, which he says has not been answered. 
5. Constitutionality of the Workmen's Compensation Act-Western Indemnity Co. v. Pillsbury ${ }^{27}$

Only a sinall and rapidly dwindling number of lawyers can actually recall the days in which an injured workman had no recourse except under the common law of negligence. That meant that he must take his case to court, prove fault on the part of the employer or a vice-principal, and then maneuver around the three yawning pitfalls of the doctrines of contributory neghigence, assumption of risk, and negligence of a fellow-servant. Some reached the goal; more did not; and the selection, made by separate juries, was capricious.

The remedy adopted is now so familiar that it is hard to realize how revolutionary it seemed. The employer was made liable to compensate his injured employees, directly or through insurance, even if the employer was in no degree at fault, and even if the employee (save for wilful misconduct or intoxication) had himself caused the accident. The decisions were taken out of the hands of judges and juries and transferred to an administrative commission. And the California statute of 1913, adopted after some cautious experiments, ${ }^{28}$ went all the way; it was made compulsory and it extended to substantially all employments. Many were scandalized.

The statute was of course attacked under the due process clause of the federal constitution, and the case reached the California Supreme Court at a precarious moment. The Supreme Court of the United States had not spoken, but the highest courts of two states had considered similar laws. The Washington statute had been upheld by its supreme court, ${ }^{20}$ but, to the great alarm of workmen's coinpensation advocates, the highly influential New York Court of Appeals had taken the contrary view..$^{30}$ No state court in the land enjoyed greater prestige; if California and other states should follow New York's lead, the workmen's compensation laws rapidly spreading through the country might go down like ten-pins.

The writing of the decision fell to Justice Sloss. He not only sustained the statute, but did so on the broadest and most sweeping grounds. He saw nothing sacred in common law rules of liability. If the Legislature sought to broaden existing liabilities or to create new classes of liability without

27170 Cal. 686, 151 Pac. 398 (1915).

28 Workmen's compensation lay near the core of Governor Hiram Johnson's progressive legislative program, but he was quite aware of the judicial hazards, and moved slowly. First, in 1911 , the Legislature enacted an elective workmen's compensation law, binding only on those employers and employees who chose to come under it; this statute was not attacked on constitutional grounds, though its interpretation presented some difficulties, as in Miller v. Pillsbury, 164 Cal. 199, 128 Pac. 327 (1912). Then a sweeping enabling provision (Art. XX, Sec. 21) was added to the state constitution, eliminating in advance many possible grounds of challenge to the plan. Only then was the 1913 statute enacted.

29 State v. Clausen, 65 Wash. 156, 117 Pac. 1101 (1911).

80 Ives v. South Buffalo Ry. Co., 201 N.Y. 271, 94 N.E. 431 (1911). 
fault, as an exercise of its power to regulate the employment relationship, there was ample ground to hold the action reasonable. ${ }^{31}$

Thus the effort toward more rational handling of the accidents that are part of the price of an industrial society overcame one of its early hurdles. Of all the members of the court, Justice Sloss was the one who viewed the experiment with the friendliest eye. ${ }^{32}$

6. The Salton Sea controversy-Title Insurance \& Trust Co. v. Cali fornia Development Co. ${ }^{33}$

Of all the decisions he was called upon to make, the Salton Sea case cost Justice Sloss the largest amount of time and labor. It has many extraordinary features, but it is particularly notable for his imaginative use of the court's equity powers.

The story takes us back to the turn of the century. The southeastern corner of Cabifornia was then a barren desert, sloping to a below-sea-level depression called the Salton Sink, useless except for the extraction of salt, for which purpose the New Liverpool Salt Company had erected a plant. A plan was devised to bring water from the Colorado River for irrigation of the fertile soil; the California Development Company was organized to accomplish that great enterprise. The most practicable route, however, led partly through Mexican territory, and Mexican law did not permit an American corporation to own land. The Development Company therefore formed a Mexican subsidiary, to hold title to the Mexican part of the canal. A bond issue was floated to finance the project; the plaintiff was the trustee under the indenture, which was secured by a mortgage on the California lands and a pledge of the stock of the Mexican subsidiary. The venture was

31 Angellotti and Lawlor went along; but Shaw would not go quite so far. He disliked the implication that the Legislature could have made employers hable even if it had not simultaneously afforded them the opportunity to limit their liability through insurance. He concurred in the decision only because of the existence of the insurance features of the statute. On this more limited ground, lie was able to draw Lorigan and Melvin with him from the other camp, leaving only Henshaw to dissent, which lie did in an opinion marked by great vigor of thought and felicity of expression. Fimally, on denial of rehearing, Sliaw voiced still another reservation; he did not believe that the act would be constitutional if it were to be applied to an injury incurred only through the employee's own negligence. On this, he stood alone.

32 This is demonstrated more clearly by the later case of Western Metal Supply Co. v. Pillsbury, 172 Cal. 407, 156 Pac. 491 (1916), holding that the constitutional authorization to provide compensation for injuries was inclusive enough to permit the Legislature to grant rights to the dependents of employees accidentally killed. The Sloss opinion goes on the broad ground that payment to dependents may be classed as a form of compensation for imjury, even though the legal origin of the two kinds of relief is quite different. None of his colleagues was willing to go that far. Angellotti (with Lawlor) concurred, but not on general principle; he relied on the circumstances under which this constitutional provision had been drafted to show an intention warranting the interpretation placed on it by the Legislature. Shaw, also concurring, repeated the reservations he had stated in the Western Indemnity case; and Henshaw, with Lorigan and Melvin now back on his side, dissented as forcefully as before.

33171 Cal. 173, 152 Pac. 542 (1915). 
a spectacular success, and the Imperial Valley blossomed into great productiveness and prosperity.

Then disaster struck. The Development Company cut a new intake to increase the diversion, and through some blunder or defect in the planning or construction, the new works proved inadequate to control the flow. When the next time of high water came, the entire flow of the Colorado plunged through the new intake, leaving its original channel, and a vast flood poured through the Imperial Valley into the Salton Sink. Thus was created the inland lake still known as the Salton Sea; in its depths remain the drownedout works of the Salt Company.

Worse was to follow. The Development Company found itself quite unable to turn the river back to its original course; if left unchecked, the new flow would gradually have inundated the whole Imperial Valley, with its thriving new farms and cities. The Development Company-backed by an appeal from the President of the United States-called on the Southern Pacific Company, whose line was also threatened, to supply the needed funds. The railroad company responded, and the river was finally turned back-but at a cost of millions of dollars and years of work. ${ }^{34}$

Naturally enough, the Southern Pacific did not propose to lay out all this money without making the best attempt possible to secure at least partial reimbursement out of the assets of the now hopelessly insolvent Development Company. But there were rival claims-first, the bondholders; second, the Salt Company, vigorously engaged in pressing to judgment its action to recover for the negligent destruction of its plant. How to obtain priority? First, the Southern Pacific had stipulated for, and obtained, control of the Development Company, which carried with it the control of the Mexican subsidiary. Then the Southern Pacific, through a newly organized Mexican subsidiary of its own, brought suit in the Mexican courts against the original Mexican company and caused the defendant to confess judgment, thus obtaining title for its own subsidiary to the Mexican part of the canal. Finally, the Southern Pacific brought suit against the Development Company in the California courts and levied an attachment on the outstanding stock of the original Mexican company. Then it sat back and waited, counting on its double hold on the Mexican assets, for how could either the bondholders or the Salt Company realize anything by a forced sale of the American part of the canal alone? Nobody but the owner of the Mexican part would bid for it, and the whole system would fall by default into the Southern Pacific's hands.

This was the scheme that was frustrated by the supreme court's de-

${ }^{34} \mathrm{~A}$ few of these facts are drawn from the opinion in Jones v. California Development Co., 173 Cal. 565, 160 Pac. 823 (1916), a later case dealing with a different aspect of the Salton Sea episode. 
cision. The trustee for the bondholders had brought all parties into court, invoking its equity powers. Those powers proved adequate for the purpose.

By taking control of the Development Company, the Southern Pacific had, according to the court, assumed fiduciary duties toward that company and its other creditors. In equity, it could not be permitted to use its control to gain an unconscionable advantage. The collusive Mexican judgment had been procured through the exercise of that control. It was proper, therefore, to direct such acts as would undo the consequences of the Mexican judgment.

But here a question of judicial power arose. Could, or should, a California court undertake to reverse what a Mexican court had decreed or to adjudicate the title to real estate outside the state? Yes, said the court; equity acts in personam; the parties were before the court; they could be compelled to do what equity required, even to the extent of being ordered to deal in a specified way with foreign land and with rights acquired in foreign courts.

In equity, then, the whole irrigation system must be dealt with as a umit. A single judicial sale of the California lands and the stock of both Mexican corporations should be ordered, and the combined proceeds should be applied first to the payment of the bonds, whose owners had the earliest lien.

As between the other two claimants, however, there were further complications. The Southern Pacific's attachment of the stock of the old Mexican company was not a breach of its fiduciary duties, since this was merely a step which any creditor might have taken without resort to collusion or control. Once the bonds were out of the way, this attachment gave the Southern Pacific priority over the Salt Company, which had not reduced its claim to judgment until later. But this priority extended only to the Mexican property. It was not equitable to dismember the system, but it was perfectly feasible to place separate money values on the Mexican and American parts by having them appraised. This was the solution adopted; the balance of the proceeds, over the amount needed to pay the bonds, was to be divided in proportion to the values of the two parts, with the Southern Pacific receiving the fraction corresponding to the Mexican assets and the Salt Company the rest. An equitable solution indeed-whether the word is used in the technical or in the layman's sense.

\section{OUTLOOK AND NATURE}

Judge Learned Hand once wrote, "men ask more than scholarship ... of a judge, and in this they are right .... In the end, and quite fairly, a judge will be estimated in terms of his outlook and his nature." ${ }^{35}$

35 HANd, TyE SPIRTT OF LIBERTY 27 (1952). 
In later years, when asked about the decisions which appeared most significant in retrospect, Judge Sloss used to speak first of the constitutional cases. We have already noted, in connection with the McEnerney Act and Workmen's Compensation Act decisions, his tendency to sustain, after thorough review of both the legal authorities and the factual background, attempts by the Legislature to exercise the police power. There are other opinions, similar in method and approach but smaller in scale. ${ }^{86}$

The decisions in what would now be called civil liberties cases are also informative. We have already seen that Justice Sloss and his closest associates were friendly to the "miscarriage of justice" amendment, even where its apphication invaded, in respects not considered material, the constitutional rights of persons accused of crime. ${ }^{37}$ These same justices were also willing to give more latitude than their colleagues to the law enforcement agencies in cases that turned on the amount of "persuasion" that will render a confession involuntary and therefore inadmissable. ${ }^{38}$

On the record, then, Justice Sloss emerges as a judge tolerant of legislative and executive action, if at all reasonable, as against claims of invasion of constitutional rights-perhaps, on the strength of the workmen's compensation decisions, the most tolerant of all. This approach was taken consistently, regardless of whether the constitutional provision was designed to protect property interests or personal rights. Should he be classed as a "hiberal judge"? Yes, but only if the term is properly understood. Justice Sloss was no "liberal" in the sense of favoring particular interests among those protected by the Bill of Rights. He approached every question with a desire to be right and without partisanship. But if by "liberal" we mean an open-minded willingness to consider on its merits any argu-

36 County of Plumas v. Wheeler, 149 Cal. 758, 87 Pac. 909 (1906), upholding a comprehensive county ordinance regulating and licensing the business of sheep raising; Laurel Hill Cemetery v. City and County of San Francisco, 152 Cal. 464, 93 Pac. 70 (1907), aff'd, 216 U.S. 358 (1910), sustaining, in spite of a contrary decision in the United States Circuit Court, the validity of the ordinance prohibiting further interments within the city limits; Application of Martin, 157 Cal. 51, 106 Pac. 235 (1909), dealing with the eight-hour day for miners. In some of these cases, Justice Sloss spoke for a unaninous court, while others reflected a sharp division. In such situations, the Department One colleagues, Shaw and Angellotti, were almost invariably of his view.

${ }^{37}$ See notes 23 and 26 supra.

${ }^{38}$ See People v. Loper, 159 Cal. 6, 112 Pac. 720 (1910). Also interesting on the extent of civil rights is Matter of Dart, the decision involving the Los Angeles ordinance regulating solicitations for charity, already mentioned (note 11 supra). Here Henshaw, perhaps carried away by his own eloquence, appeared disposed to hold any attempt to restrict such solicitations unconstitutional as both an invasion of individual liberty and an interference with the free exercise of religion; the right at least of churches to raise money would have been erected into an absolute, subject to no regulation whatever. Only Lorigan and Melvin agreed; Sloss was among those who concurred in the decision on the limited ground that this particular ordinance lacked adequate standards. 
ment, however novel, or to view without prejudice any experiment, however controversial, the term sums up his outlook. ${ }^{39}$

The second field Judge Sloss singled out for comment was water rights. The court was constantly aware of the fact that it was making new law as it went along, because common law precedents did not suit the climatic and agricultural conditions of this state. Over and over again, the court was called upon to interpret and apply anew the "California doctrine" based upon the primacy of riparian rights and the limited effect given to appropriation. It was also necessary to fit into this pattern the growing body of law about percolating waters. Out of this creative activity there emerged, in the best common law tradition, a comprehensive set of rules and principles. ${ }^{40}$

We have already seen that the name most prominently associated with water cases was that of Justice Shaw. Justice Sloss, however, was no mere spectator, and those water opinions that he did write reveal his mastery of the field. ${ }^{41}$ Water litigation was to remain a major activity during his subsequent years of private practice. ${ }^{42}$

In constitutional and water cases, as we have seen, the court was aware of the need to improvise; it was striking out in new directions. ${ }^{43}$ In conven-

${ }^{39} \mathrm{It}$ is in cases of this kind that the different philosophies of the two wings of the court, coinciding with the department lines, become apparent. The best glimpse we get of the inner workings of the court and its members comes from the explanation offered by the court for its abortive attempt to grant a learing in the Ruef appeal (People v. Ruef, 14 Cal. App. 621, 114 Pac. 48 (1911)). We are told just what each justice did, and their behavior ran true to form. Henshaw acted decisively and promptly-too promptly, for his vote was later held ineffective; Lorigan and Melvin followed his lead; Shaw, Angellotti and Sloss lined up in opposition; and Beatty pondered till the last moment and then voted, as usual, to grant the hearing. These disagreements, however, should not be overstressed; it would be quite wrong to picture this court as an arena in which two clashing groups were constantly at loggerheads. Cases with dissents, although unusually interesting, remained rare; in the overwhelming majority of decisions the whole court was of the same view. In private litigation, moreover, the departunental line-up broke down; differences of opinion, where they occurred, were individual.

40 Perhaps the rules became too rigidly set; a later court was to give an extreme application to the principle of riparian supremacy in the much criticized case of Herminghaus v. Southem California Edison Co., 200 Cal. 81, 252 Pac. 607 (1926). This decision provoked a reaction in the form of a constitutional amendment (Art. XIV, sec. 3, added in 1928), limiting the riparian right to the amount reasonably required for beneficial use; Judge Sloss played an important part in its adoption.

41 See, for example, Huffner v. Sawday, 153 Cal. 86, 94 Pac. 424 (1908), Miller \& Lux v. Madera Canal \& Irrigation Co., 155 Cal. 59, 99 Pac. 502 (1909), and Lindblom v. Round Valley Water Co., 178 Cal. 450, 173 Pac. 994 (1918).

42 Especially his participation in Tulare Irrigation District v. Lindsay-Strathmore Irrigation District, 3 Cal. 2d 489, 45 P.2d 972 (1935), probably the bitterest and most protracted battle of its kind in California's history; and in Meridian Itd. v. City and County of San Francisco, 13 Cal. 2d 424, 90 P.2d 537 (1939), the case that defined the extent of San Francisco's rights in connection with the Hetch Hetchy project.

43 In view of the Parkinson case (note 15 supra), perhaps the same should be said of labor law. 
tional litigation as well, however, much can be seen about the nature of the man under the robe; it is only necessary to search a bittle more deeply to ascertain the basic values that motivate him in certain cases to go somewhat beyond a mere mechanical application of the law as he finds it.

One of the strongest motivating values for Justice Sloss was his passion -if the word may be used in speaking of one so dispassionate-for fair, open and honorable dealing. The taking of undue advantage, the repudiation of obligations, or trickery in any form was not to be countenanced. We have seen an example in the Salton Sea case, ${ }^{44}$ where the entire structure of the elaborate conclusion rests on the refusal to permit a party to retain an advantage gained by over-reaching. Another instance or two may be of interest.

On its face, Barendt v. McCarthy, ${ }^{45}$ in which the court divided four to three, involved only a question of procedure. The Mayor of San Francisco had removed the old Board of Health and appointed a new one. The new Board went to the office, found it unoccupied but locked, procured a locksmith, and thus gained admittance and took possession. The old Board brought suit for injunction. The majority of the court held that an injunction suit was not the proper proceeding in which to try the question of title to a public office; let the old Board proceed by quo warranto. This was too much for Justice Sloss, who wrote the dissenting opinion. He did not believe that the new Board should be able to gain even a procedural advantage by a surreptitious maneuver. Entry obtained in this manner should be disregarded; the old Board should be treated as still in possession and entitled to protection of its possession by injunction. It was the new Board and not the old that should be remitted to quo warranto proceedings.

Dislike of attempts to repudiate agreements was illustrated by Schulte v. Boulevard Gardens Land $\mathrm{Co}^{46}$ Here, a corporation had issued its stock under an express agreement to repurchase it at the option of the buyer. When the stockholder sought to exercise the option, the corporation tried to avoid its obligation, relying on the settled rule that a corporation was not permitted to purchase its own stock. The decision by Justice Sloss creates an exception to the rule, permitting the purchase to be made where it is necessary in order to carry out an express agreement and where creditors will not be adversely affected. That exception still exists under the present code.

Another of his strong convictions was that, within the limits of fair and proper dealing, individuals should be as free as possible to make such arrangements as they desire. An interesting example, which has had lasting

\footnotetext{
44 See text at note 33 supra.

45160 Cal. 680, 118 Pac. 228 (1911).

46164 Cal. 464, 129 Pac. 582 (1913).
} 
consequences, is his landmark opinion in Grogan v. Chaffee, ${ }^{47}$ in which the court held, in the face of a contrary decision by the United States Circuit Court of Appeals, that a contract for resale price maintenance (in the absence of a prohibiting statute) was not invalid as a restraint of trade. ${ }^{48}$

The Spreckels case ${ }^{49}$ has shown us how Justice Sloss disliked needless restrictions on the power of testators to dispose of their property. A similar problem provoked the divided decision in Estate of Emart. ${ }^{50}$ Here, the court was called on for the first time to decide whether both witnesses to a will must be present at the saine inoment, or whether the testator may acknowledge it to them one at a time; the statute did not then expressly require, as it now does, that both be present. The majority of the court concluded that the Califorma code provisions with respect to the formalities of attestation were modeled more closely on the English Wills Act of 1837 than on the earlier Statute of Frauds, and the Wills Act required joint presence. Justice Sloss, however, preferred freedom over strict logic. His dissenting opinion goes mainly on the simple ground that the code did not expressly contain this precise requirement, and the courts were not "justified in reading into the law a demand for the performance of any act or formality not included within its terms." 51

Sometimes Justice Sloss declined to extend a rule to new situations in which its application would be unreasonable. One notable case of this kind is In re Collins. ${ }^{52}$ There a defendant had been brought back from Canada on extradition proceedings to be tried for perjury. The jury disagreed, and no attempt was inade to try him again on the original charge; but he was then indicted for a fresl perjury committed in the trial. The defendant urged the general rule that a man cannot be extradited for one offense and then tried for another, since that would constitute a fraud on the nation permitting the extradition. It was held, in a unanimous decision by Justice Sloss, that this rule applied only to other offenses previously committed; an extradition proceeding did not constitute a license to commit new crimes thereafter with impunity.

47156 Cal. 611, 105 Pac. 745 (1909).

48 A subsequent decision extended the rule by permitting enforcement not only against the signer of such an agreement but also against more remote purchasers, D. Ghirardelli Co. v. Hunsicker, 164 Cal. 355, 128 Pac. 1041 (1912). When, many years later, California enacted one of the earhest fair trade statutes, designed to permit resale price maintenance notwithstanding the anti-trust laws, the existence in California of common law support for the policy of price maintenance was strongly relied on in persuading the supreme court to uphold the act. Max Factor \& Co. v. Kunsman, 5 Cal. 2d 446, 55 P.2d 177, in which Judge Sloss made the principal argument in support of the statute, $a f^{\prime} d, 299$ U.S. 198 (1936).

40 See text at note 19 supra.

50175 Cal. 238, 165 Pac. 707 (1917).

51175 Cal. at 249, 165 Pac. at 712 .

52 151 Cal. 340, 90 Pac. 827 (1907) ; affd, Collins v. O'Neill, 214 U.S. 113 (1909). 
A similar emphasis on what is reasonable is exemplified in the well known contract case of Mineral Park Land Co. v. Howard, ${ }^{63}$ holding that the defense of impossibility should be extended to situations in which performance, though not strictly impossible, could have been accomplished only at unreasonable and impractical cost quite beyond the contemplation of the parties.

Where two interpretations were possible, the practical consequences were never overlooked. In Tidewater Southern Railway Co. v. Jordan $n^{\text {t4 }}$ the court had to interpret a statutory requirement that certain kinds of corporate action must be taken by the unanimous vote of the Board of Directors. The opinion by Justice Sloss held that the requirement was satisfied if there was a quorum and if all those present concurred in the resolution; it would be impractical to insist that every member of the Board must be present before action could be taken. Respect for settled practice appears again in the case which held that a complaint consisting of a common count is good against special demurrer..$^{55}$ It was recognized that the common count was logically inconsistent with the entire theory of code pleading; if the question had arisen when the codes were new, it might better have been decided the other way; but the inconsistency was not important enough to justify upsetting the long-established habits of the Bar.

We find in many of these decisions a sensitivity to the gradual changes of view characteristic of the common law. Traditionally, courts had looked with disfavor on statutes of limitations; they were commonly regarded as technical devices by which men could escape just obligations. It fell to Justice Sloss, in Lilly-Brackett Co. v. Sonnemann, ${ }^{\text {b6 }}$ to examine the growing belief that statutes of limitations produce repose and stability and to conclude that they were increasingly coming to be viewed with favor. The statute of limitations, he held, should therefore be classed as a meritorious defense.

On one occasion, perhaps, his instinct for the direction in which the law was likely to advance failed him. This was the controversial "Tipo" case on trademarks and unfair competition. ${ }^{57}$ Then, as now, the Italian Swiss Colony was well known for its "Tipo Chianti" wines, which were commonly ordered by customers simply as "tipo red" or "tipo white." The question was whether another producer of wine could be restrained from the mere use of the Italian word "tipo," meaning "type," to designate wines similar to particular Italian varieties. The court was unanimous in the view that "tipo" could not be appropriated as a trademark, since it was an ordi-

\footnotetext{
53 I72 Cal. 289, 156 Pac. 458 (1916).

54 163 Cal. 105, 124 Pac. 716 (1912).

55 Pike v. Zadig, 171 Cal. 273, 152 Pac. 923 (1915).

56157 Cal. 192, 106 Pac. 715 (1910).

67 Italian Swiss Colony v. Italian Vineyard Co., 158 Cal. 252, 110 Pac. 913 (1910).
} 
nary word, although in a foreign language. Whether the word had acquired a secondary meaning, however, so as to be entitled to protection under the doctrine of unfair competition, provoked a disagreenıent. The majority opinion, by Justice Sloss, denied relief; three justices dissented. It seems probable that the case would go the other way today. ${ }^{58}$

Coupled with Judge Sloss's cool head went a warm heart; pure logic often fell before the need to protect someone from social disadvantage or injustice. In Coats $v$. Coats, ${ }^{59}$ a marriage was annulled at the instance of the husband after almost twenty years, but the trial court, in its discretion, awarded the former wife a share of the property accumulated out of the husband's earnings during the existence of the marriage. There was little authority to sustain his action, and on strict legal reasoning it had no logical basis, for the annulment, unlike a divorce, had terminated the marriage from the start, and if there had never been a marriage, there could be no community property. On general equitable principles, however, the opinion by Justice Sloss sustained the award to the wife.

Concern for children led to similar results. Estate of $S h i p p^{60}$ involved a child whose parents had gone through a marriage ceremony performed by a priest, but without a license or the other formalities needed to entitle the marriage to legal recognition. It became necessary to determine whether the child was legitimate. The code provided that the issue of a marriage "null in law" is legitimate, but it was contended that this provision referred only to a nuarriage validly performed but subject to annulment on one of the grounds specified in the code, and did not apply where there had legally been no marriage whatever. Relying heavily on the desirability of the contrary result, however, the opinion by Justice Sloss holds that the code should be interpreted liberally to protect the child from the stigma of illegitimacy.

The warmest and kindliest impulses can nevertheless go astray without the wisdom to recognize the course most likely to promote human welfare. Estate of Jobson, ${ }^{61}$ decided when adoption laws and procedures were still primitive, presented plausible alternatives; history has vindicated the farsighted choice embodied in Justice Sloss's decision that adoption had permanently terminated the parental relationship between a child and his original parents. ${ }^{62}$

58 The majority did not anticipate the growth in the law of unfair competition, beyond cases of fraudulent "passing off" of the defendant's goods, to cover the situation of an attempt to take a "free ride" on the plaintiff's good will.

59 160 Cal. 671, 118 Pac. 441 (1911).

60 168 Cal. 640, 144 Pac. 143 (1914).

61 164 Cal. 312, 128 Pac. 938 (1912).

$62 \mathrm{~A}$ child had been adopted by a relative; later the adopting parent died, leaving his estate to the adopted child; still later, the adopted child died intestate. The question was whether the natural father, who survived, was an heir-a question not then covered by statute. The SIoss 
Humanitarianism is often broader than concern for humanity alone, and we may therefore note in passing the decision in Estate of Coleman, ${ }^{\text {os }}$ upholding a bequest for the erection and nuaintenance of a fountain for the benefit of thirsty aninuals and birds as a proper charitable trust. ${ }^{04}$

Many more cases could be singled out for discussion, but these are enough; we are here looking only for the outlook and nature of the nuan. We have found tolerance of arguments and experiments, however novel, if they are honest and reasonable, with intolerance only of deceit, trickery and abuse of power; respect for learning and reason, but not at needless cost to the right of men to conduct their affairs in a free and practical way; appreciation of stability and order but not to the point of stifling those changes that new conditions continually require; concern for hunian welfare, especially for those under some handicap or disadvantage; and, above all, the wisdom to recognize the course most likely to proniote the ends the law seeks to serve. Are not these the signs which set apart from the many good craftsmen who happen to occupy the bench the rare man who can properly be called a great judge?

majority opinion held that the adoption had permanently terminated the parental relationship between the child and his original father. Shaw dissented. He recognized that the statute created a new parental relationship with the adopting parents, and severed the original relationship; but he believed that the new status should, like a marriage, exist only during the joint lives of the parties, and that on the death of the adopting parents, the rights and duties of the original parents should revive. This, he thought, would give greater protection to the child by keeping a second set of parents in reserve. Today it is fundamental in adoption theory and practice that the termination of the old parental relationship, as well as the creation of the new one, is permanent and final for all purposes.

63 167 Cal. 212, 138 Pac. 992 (1914).

04 Two other decisions have an element of special interest for those acquainted with Judge Sloss's family hife. To appreciate their understones, it is necessary to know that of the many civic activities with which Mrs. Sloss concerned herself, two were the closest to her heart. One was the cause of child welfare, and in particular the activities of the Children's Agency under the direction of the distinguished and indefatigable Katharine Felton, who was responsible for the creation of what was known as the "San Francisco Public-Private Plan" under which neglected or deserted children were committed by the Juvenile Court to the custody of one of the private child care agencies. The other was music, including the long struggle on the part of the Musical Association of San Francisco to procure the erection of a municipally owned opera house. It must, then, have caused Justice Sloss particular satisfaction to write the opinion in Matter of Maginnis, 162 Cal. 200, 121 Pac. 723 (1912), upholding the legality of a commitment to the Children's Agency under the "Public-Private Plan" for child welfare. Conversely, it must have been a sad day on which he was compelled to speak for the court in bolding invalid a contract between the City and the Musical Association under which the construction of the opera house was about to go forward-a decision which delayed for almost twenty years the realization of that cherished dream. Egan v. City and County of San Francisco, $165 \mathrm{Cal}$. 576, 133 Pac. 294 (1913). It has been observed before that when the Opera House finally opened its doors in 1932, the first words sung from its stage were the Itahan equivalent of "Ahl At last l" It has not been generally noticed that the character in "Tosca" who sings those words is named Angelotti-a coincidence from which Judge Sloss, although only an occasional and reluctant opera-goer, derived amusement. 